\author{
Ilona Tomczyk-Wydrych ${ }^{\mathrm{a}}$, Anna Rabajczyk ${ }^{\mathrm{b}}{ }^{*}$ \\ a) The State Water Holding Polish Waters / Państwowe Gospodarstwo Wodne Wody Polskie \\ b) Scientific and Research Centre for Fire Protection - National Research Institute / Centrum Naukowo-Badawcze Ochrony \\ Przeciwpożarowej im. Józefa Tuliszkowskiego - Państwowy Instytut Badawczy \\ *Corresponding author / Autor korespondencyjny: arabajczyk@cnbop.pl
}

\title{
Transformations of Metal Nanoparticles in the Aquatic Environment and Threat to Environmental Safety
}

\section{Przemiany nanocząsteczek metali w środowisku wodnym i zagrożenie dla bezpieczeństwa środowiskowego}

\begin{abstract}
Purpose: The aim of the article is to provide information on the transformation and interaction of metal nanoparticles in the aquatic environment. Introduction: Nanotechnology is one of the leading fields of science, combining knowledge in the fields of physics, chemistry, biology, medicine, computer science and engineering. Nanoparticles of heavy metals, due to their structure and size, exhibit new important biological, chemical and physical properties, which are impossible to achieve at the level of macro- and microscopic structures. Nanoparticles of metal and metal oxides (NPMOs) are promising substances with a wide spectrum of applications in many areas. The increasing number of products based on (NPMOs) leads to the emission of an increasing amount of these substances in various forms to the environment. The presence of NPMOs in industrial and municipal sewage affects their further migration to surface waters and soils, which in turn also leads to their introduction into the food chain. Therefore, understanding the properties and behaviour of these substances in aqueous solutions is becoming a priority in the field of safety, environmental protection and human health. Methodology: The article was prepared on the basis of a review of the literature on the subject.

Conclusions: Nanoparticles of metals and metal oxides are widely used in various areas of human life, which means that they constitute an increasingly important group of compounds released to the environment, including to surface waters. Nanoparticles of metal and metal oxides play an important role in the aquatic environment, affecting numerous biophysicochemical processes. However, it should be noted that many of the processes that NPMOs undergo are determined by the size of the grains and surfaces of nanoparticles, and the metals that form the basis of these nanosubstances. Processes such as agglomeration, sedimentation, sorption on the surface of organisms, oxidation and catalysis are conditioned by numerous parameters such as the presence of other substances, the acidification/alkalization of the aquatic environment, and the presence of plant and animal organisms. In order to assess the actual or potential threat to the environment or human exposure, it is necessary to explore the mechanisms and kinetics of processes occurring in the aquatic environment with respect to nanoparticles of metals and metal oxides. Knowledge of NPMOs processes in the aquatic environment is necessary to create or enhance environmental migration models.

Keywords: metal nanoparticles, surface waters, migration, transformations
\end{abstract}

Type of article: review article

Received: 06.11.2019; Reviewed: 19.12.2019; Accepted: 19.12.2019;

Authors' ORCID IDs: I. Tomczyk-Wydrych - 0000-0002-1278-2615; A. Rabajczyk - 0000-0003-4476-8428;

The authors contributed the equally to this article;

Please cite as: SFT Vol. 54 Issue 2, 2019, pp. 54-68, https://doi.org/10.12845/sft.54.2.2019.4;

This is an open access article under the CC BY-SA 4.0 license (https://creativecommons.org/licenses/by-sa/4.0/).

\begin{abstract}
ABSTRAKT
Cel: Celem artykułu jest przedstawienie informacji na temat przemian i interakcji nanocząstek metali zachodzących w środowisku wodnym Wprowadzenie: Nanotechnologia to jedna z wiodących dziedzin nauki, łącząca wiedzę z obszaru fizyki, chemii, biologii, medycyny, informatyki i inżynierii. Nanocząstki metali ciężkich, ze względu na budowę i rozmiary, wykazują nowe istotne właściwości biologiczne, chemiczne oraz fizyczne, niemożliwe do osiągnięcia na poziomie makro- i mikroskopowych struktur. Nanocząstki metali i tlenków metali są atrakcyjnymi substancjami o szerokim spektrum zastosowań w wielu dziedzinach. Wzrost produkcji wyrobów z wykorzystaniem nanocząstek metali i tlenków metali (NPMOs) sprawia, że coraz większa liczba tych substancji przedostaje się do środowiska. Obecność NPMOs w ściekach przemysłowych i miejskich wpływa na ich dalszą migrację do wód powierzchniowych oraz gleb, co w konsekwencji skutkuje także wprowadzeniem ich do łańcucha pokarmowego. Dlatego też poznanie właściwości i zachowania tych substancji w roztworach wodnych staje się priorytetem w dziedzinie bezpieczeństwa, ochrony środowiska i człowieka.
\end{abstract}


Metodologia: Artykuł został opracowany na podstawie przeglądu literatury z zakresu poruszanej tematyki.

Wnioski: Nanocząstki metali i tlenków metali są powszechnie stosowane w różnych dziedzinach życia człowieka, co powoduje, że stanowią coraz bardziej istotną grupę związków emitowanych do środowiska, w tym do wód powierzchniowych. Nanocząstki metali i tlenków metali odgrywają istotną rolę w środowisku wodnym, determinując liczne procesy biofızykochemiczne. Należy jednak zaznaczyć, że wiele procesów, którym ulegają NPMOs, uwarunkowana jest wielkością ziaren i powierzchni nanocząstek oraz metalami, stanowiących bazę tych nanosubstancji. Procesy takie jak aglomeracja, sedymentacja, sorpcja na powierzchni organizmów, utlenianie czy kataliza, uwarunkowane są licznymi parametrami, m. in. obecnością innych substancji, zakwaszeniem/alkalizacją środowiska wodnego, obecnością organizmów roślinnych i zwierzęcych. Konieczne jest poznanie mechanizmów oraz kinetyki procesów zachodzących w środowisku wodnym w odniesieniu do nanocząstek metali i tlenków metali w celu oszacowania rzeczywistego lub potencjalnego zagrożenia dla środowiska lub narażenia ludzi. Wiedza w zakresie procesów, jakim ulegają NPMOs w środowisku wodnym, jest niezbędna w celu stworzenie lub dopracowania już funkcjonujących modeli migracji zanieczyszczeń w środowisku.

Słowa kluczowe: wody powierzchniowe, migracja, transformacje, nanocząstki metali

Typ artykułu: artykuł przeglądowy

Przyjęty: 06.11.2019; Zrecenzowany: 19.12.2019; Zatwierdzony: 19.12.2019;

Identyfikatory ORCID autorów: I. Tomczyk-Wydrych - 0000-0002-1278-2615; A. Rabajczyk - 0000-0003-4476-8428;

Autorzy wnieśli równy wkład merytoryczny w powstanie artykułu;

Proszę cytować: SFT Vol. 54 Issue 2, 2019, pp. 54-68, https://doi.org/10.12845/sft.54.2.2019.4;

Artykuł udostępniany na licencji CC BY-SA 4.0 (https://creativecommons.org/licenses/by-sa/4.0/).

\section{Introduction}

Nanotechnology refers to objects with at least one dimension within the range of 1 to $100 \mathrm{~nm}$. Currently it is one of the leading fields of science, combining physics, chemistry, biology, medicine, computer science and engineering. Due to their structure and size, nanoparticles of heavy metals exhibit new important biological, chemical and physical properties, which are impossible to achieve at the level of macro- and microscopic structures. Their large surface area, superparamagnetic properties, excellent sorption capacity, crystal structure diversity and the nature of bonds make nanoparticles promising substances with a wide spectrum of applications in a number of areas.

The increasing number of products based on nanoparticles of metal and metal oxides NPMOs, leads to the emission of an increasing amount of these substances in various forms to the environment. The presence of NPMOs in industrial and municipal sewage affects their further migration to surface waters and soils, which in turn also leads to their introduction into the food chain. Therefore, understanding the properties and behaviour of these substances in aqueous solutions is becoming a priority in the field of safety, environmental protection and human health.

The behaviour of these substances may present a threat to the environment and the public. Determining the features and stability of nanoparticles is very important, as it also allows us to understand their functioning in aqueous solutions and interactions with the basic substances present in the environment.

\section{Sources of emission to the aquatic environment}

Nanoparticles are released to the environment as a result of natural and anthropogenic processes (Figure 1). The increasing use of nanosubstances, in both cosmetic and industrial prod-

\section{Wprowadzenie}

Nanotechnologia odnosi się do obiektów, których przynajmniej jeden wymiar zawiera się w przedziale 1-100 nm. Obecnie to jedna z wiodących dziedzin nauki, łącząca wiedzę z obszaru fizyki, chemii, biologii, medycyny, informatyki i inżynierii. Nanocząstki metali ciężkich, ze względu na budowę i rozmiary, wykazują nowe istotne właściwości biologiczne, chemiczne oraz fizyczne, niemożliwe do osiągnięcia na poziomie makro-i mikroskopowych struktur. Duża powierzchnia właściwa, właściwości superparamagnetyczne, doskonała zdolność sorpcyjna, różnorodność struktury kryształów i charakter wiązań powodują, że nanocząstki są interesującymi substancjami o szerokim spektrum zastosowań w wielu dziedzinach.

Wzrost produkcji wyrobów z wykorzystaniem nanocząstek metali i tlenków metali (NPMOs) sprawia, że coraz większa liczba tych substancji przedostaje się do środowiska. Obecność NPMOs w ściekach przemysłowych i miejskich powoduje ich dalszą migrację do wód powierzchniowych oraz gleb, a w konsekwencji także wprowadzenie ich do łańcucha pokarmowego. Dlatego też poznanie właściwości i zachowania tych substancji w roztworach wodnych staje się priorytetem $w$ dziedzinie bezpieczeństwa, ochrony środowiska i człowieka.

Przemiany i zachowanie się tych zanieczyszczeń mogą stanowić potencjalne zagrożenie dla środowiska oraz człowieka. Określenie cech i stabilności nanocząstek jest bardzo istotne, gdyż pozwala także zrozumieć ich funkcjonowanie w roztworach wodnych oraz interakcji z podstawowymi substancjami obecnymi w środowisku.

\section{Źródła emisji do środowiska wodnego}

Nanocząstki są emitowane do środowiska w wyniku naturalnych i antropogenicznych procesów (ryc. 1). Rosnące wykorzystanie nanosubstancji, zarówno w produktach komercyjnych, jak 
ucts, as well as their great diversity, contributes to the increasing concentration and variety of those substances in aquatic ecosystems [1]. i przemysłowych, oraz ich ogromna różnorodność determinuje coraz większe stężenie i zróżnicowanie tych substancji w ekosystemach wodnych [1].

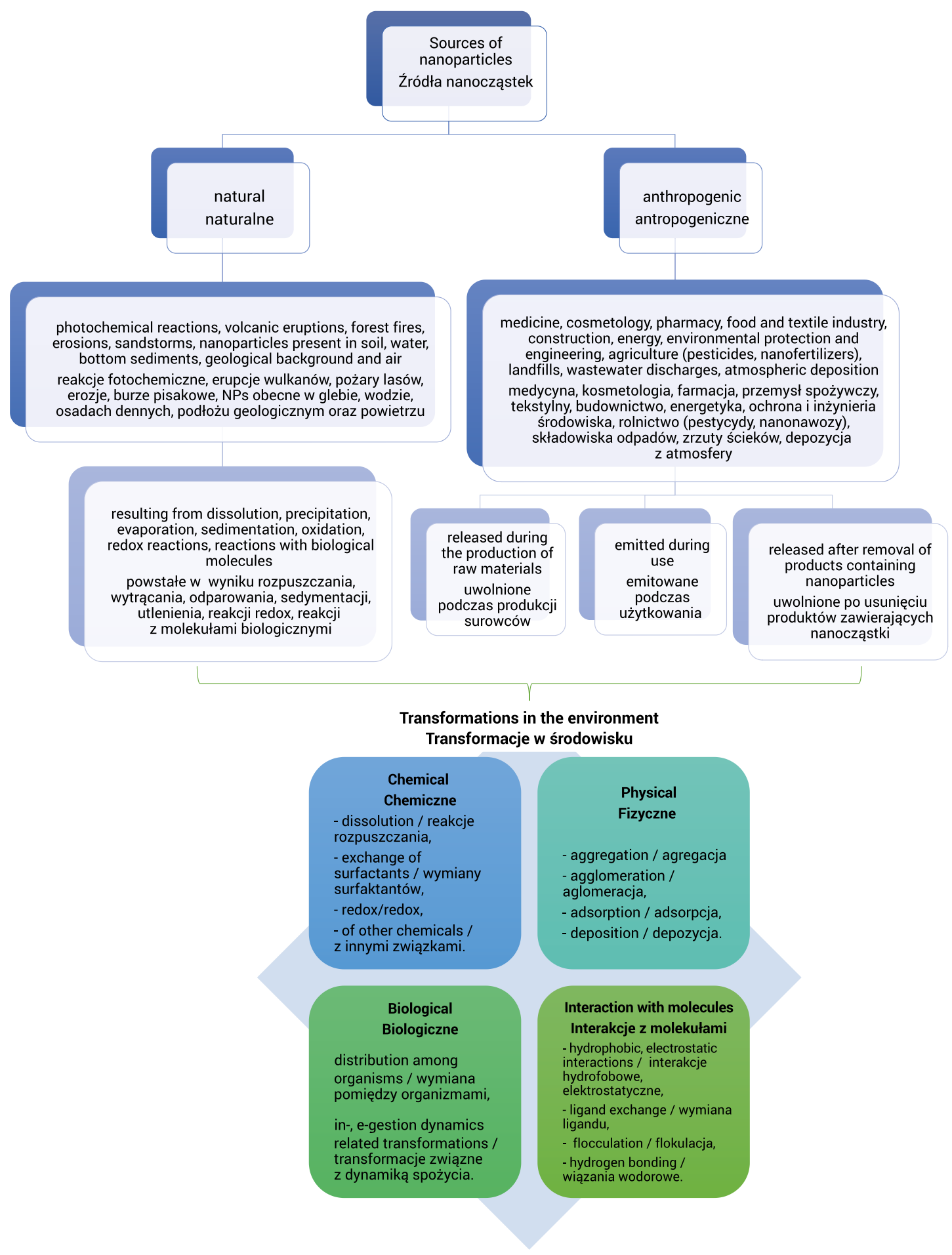

Figure 1. Emission sources and transformation processes of nanoparticles in the environment

Rycina 1. Źródła emisji i procesy transformacji nanocząstek zachodzące w środowisku

Source: Own study based on [2-5].

Źródło: Opracowanie własne na podstawie [2-5]. 
The surface water environment is continually subject to anthropopressure. Pollutants introduced directly or indirectly to water ecosystems undergo physico-chemical/biological and hydrological processes. The number and type of pollutant loads are determined by the physico-chemical properties of water, hydrogeological conditions and the degree of catchment area development [2], [6-7]. Nanoparticles present in the environment can therefore assume a variety of forms, such as aggregated (homo and heteroaggregation), dissolved, mineralised, oxidised and bound to biological structures by sorption [2].

Nanostructures may reach surface waters in various ways. Introduced into the atmosphere, they may be subject to deposition on the surface of soil or various civil structures and then migrate into waters as a result of, i.a., surface runoff. Nanosubstances released directly to watercourses are capable of accumulating in bottom sediments as a result of sorption and sedimentation processes. Subsequently, participating in changes such as e.g. disaggregation, dissolution, or physical, chemical and biological transformation, they can affect the functioning of organisms inhabiting a given ecosystem. NPMOs participate in chemical reactions, including i.a. organic compound mineralisation (e.g. NOM), as a result of which nanoparticles can be released to soil and water solutions.

Nanoparticles present in surface waters migrate along with the waters. However, it should be pointed out that most reactions and processes, which occur in water, take place at the phase boundary. solution - solid phase. Some pollutants are deposited on the surface of particles and other solid bodies present in water and it is therethat further transformation occurs [9].

The transport and transformation of nanoparticles in the aquatic environment are determined by various parameters, which decide, i.a. about solubility and therefore affect the form in which these substances occur (Table 1).
Środowisko wód powierzchniowych poddawane jest nieustającej antropopresji. Zanieczyszczenia wprowadzane w sposób bezpośredni lub pośredni do ekosystemów wodnych podlegają procesom fizyko-chemiczno-biologicznym oraz hydrologicznym. Liczba i rodzaj ładunków zanieczyszczeń uzależnione są od właściwości fizykochemicznych wody, warunków hydrogeologicznych oraz stopnia zagospodarowania zlewni [2], [6-7]. Nanocząstki występujące w środowisku mogą przybierać zatem formy zagregowane (homo-, hetero- agregacja), rozpuszczone, zmineralizowane, utlenione oraz połączone ze strukturami biologicznymi w wyniku sorpcji [2].

Nanostruktury dostają się do wód powierzchniowych różnymi drogami. Wprowadzone do atmosfery mogą ulegać depozycji na powierzchni gleby, różnych obiektów budowlanych, a następnie na skutek m.in. spływu powierzchniowego migrować do wód. Nanosubstancje emitowane bezpośrednio do cieków są w stanie kumulować się w osadach dennych w wyniku procesów sorpcji i sedymentacji. Następnie, uczestnicząc w przemianach takich jak np. dezagregacja, rozpuszczanie, transformacja fizyczna, chemiczna i biologiczna, mogą wpływać na funkcjonalność organizmów bytujących w danych ekosystemach. NPMOs uczestniczą w reakcjach chemicznych, w tym m.in. mineralizacji związków organicznych (np. NOM), na skutek czego może dojść do uwolnienia nanocząstek do roztworów glebowych i wody [8].

Nanozwiązki obecne w wodach powierzchniowych migrują wraz z wodami. Należy jednak zaznaczyć, że większość reakcji i procesów, które zachodzą w wodzie, odbywa się na granicy faz: roztwór - faza stała. Niektóre zanieczyszczenia zatrzymane są wręcz na powierzchni cząstek i innych ciał stałych znajdujących się w wodzie i tam dochodzi do dalszych przemian [9].

Transport i przemiany nanocząstek w środowisku wodnym uwarunkowane są różnymi parametrami, które decydują m.in. o rozpuszczalności i tym samym wpływają na formę występowania tych substancji (tab. 1).

Table 1. Mobility of metal nanoparticles in the aquatic environment

Tabela 1. Mobilność nanocząstek metali w środowisku wodnym

\begin{tabular}{|c|c|}
\hline $\begin{array}{l}\text { Factor } \\
\text { Parametr }\end{array}$ & $\begin{array}{l}\text { Processes } \\
\text { Procesy }\end{array}$ \\
\hline $\mathrm{pH}$ & $\begin{array}{l}\text { influence on solubility, aggregation, oxidation } \\
\text { wpływ na rozpuszczalność, agregację, utlenianie }\end{array}$ \\
\hline $\begin{array}{l}\text { type of nanoparticle } \\
\text { rodzaj nanocząstki }\end{array}$ & $\begin{array}{l}\text { variable mobility } \\
\text { zróżnicowana mobilność }\end{array}$ \\
\hline $\begin{array}{l}\text { hydrophilicity } \\
\text { hydrofilowość }\end{array}$ & $\begin{array}{l}\text { hydrophobic substances tend to agglomerate or absorb faster } \\
\text { hydrofobowe substancje mają tendencję do szybszej aglomeracji lub absorpcji }\end{array}$ \\
\hline $\begin{array}{l}\text { coating } \\
\text { pokrycie i powłoka }\end{array}$ & $\begin{array}{l}\text { natural or intentional modifications can prevent coagulation, agglomeration and increase mobility } \\
\text { naturalne lub celowe modyfikacje mogą zapobiec krzepnięciu, aglomeracji i zwiększyć mobilność }\end{array}$ \\
\hline $\begin{array}{l}\text { size } \\
\text { rozmiar }\end{array}$ & $\begin{array}{l}\text { smaller particles sediment and settle more slowly than larger ones, and migrate more easily inside organisms } \\
\text { mniejsze cząstki ulegają sedymentacji, osadzaniu wolniej niż większe, łatwiej migrują wewnątrz organizmów }\end{array}$ \\
\hline $\begin{array}{c}\text { surface } \\
\text { powierzchnia }\end{array}$ & $\begin{array}{l}\text { a large surface determines the high potential } \\
\text { rozbudowana powierzchnia determinuje jej wysoki potencjał }\end{array}$ \\
\hline $\begin{array}{l}\text { the presence of other compounds, } \\
\text { e.g. NOM, Cl-, SO42- } \\
\text { obecność innych związków } \\
\text { np. NOM, Cl-, SO42- }\end{array}$ & $\begin{array}{l}\text { other compounds determine aggregation and agglomeration, dissolution, oxidation and reduction, creation of } \\
\text { new solid forms and thus the possibility of sedimentation and migration processes in the aquatic environment } \\
\text { determinują agregację i aglomerację, rozpuszczanie, utlenianie i redukcję, tworzenie nowych form stałych i tym } \\
\text { samym możliwość procesów sedymentacji i migracji w środowisku wodnym }\end{array}$ \\
\hline
\end{tabular}

Source: Own elaboration based on [2], [10-15]

Źródło: Opracowanie własne na podstawie [2], [10-15]. 
It should be noted that the uncontrolled introduction of metal nanoparticles and metal oxides to the environment is particularly dangerous due to their durability and accumulation in organisms, since, similarly to metals in the macro scale, they are not subject to biodegradation, even if they are supplied periodically and in limited amounts. It is therefore necessary to conduct research at the molecular level to determine the stability, solubility and aggregation of nanoparticles, which may affect their fate, toxicity, bioavailablity and durability in the environment. One of the factors playing an important role in the processes taking place in the aquatic environment is the presence of microorganisms, natural matter and a variety of inorganic ions.

\section{Interactions with natural organic matter}

Natural waters contain a large number of particles of various sizes, including organic matter. Natural organic matter (NOM) is mainly from plants or residues of microogranisms. In its original or chemically transformed form, organic matter (OM) may migrate from the soil into the hydrosphere. This transport is usually connected with rainfall, which either runs off or soaks through the soil column, transporting the dissolved and suspended NOM particles to streams, lakes and oceans, or into the ground, feeding groundwater. Organic matter which comes from land sources is a significant part of the total amount of organic matter, particularly in small, continental water bodies. OM also forms in situ in water bodies, an excellent example of which is wetlands, both natural and artificial. Intensive plant growth leads to the formation of a thick layer of aerated matter and roots, which remain in the water after dying. It has been estimated that about $10 \%$ of global microbial activity in water is used to produce dissolved organic matter [16].

It should be emphasised that in addition to natural sources, anthropogenic sources provide specific organic compounds such as substances used in agriculture, medicinal preparations, products or waste from industrial processes, landfill leachate, wastewater containing phenols, surfactants, polycyclic aromatic hydrocarbons, chlorinated organic compounds and petroleum compounds [17].

Organic matter particles are divided into three classes, or categories:

I. Fulvic acids (FA) - soluble in water across a wide $\mathrm{pH}$ range.

II. Humin acids $(\mathrm{HnA})$ - humic fraction that is not soluble in water in a strongly acidic environment $(\mathrm{pH} 2)$, but soluble in higher $\mathrm{pH}$ values.

III. Humins $(\mathrm{Hu})-$ insoluble in water at all pH's [18].

Humic substances (HS) are complex compounds forming part of the humus and included in the suspension [19-20].

An important feature of humic substances is their potential to produce soluble or insoluble water complexes with metal ions, metal oxides, minerals or hydroxides. HS also exhibit the capability of interacting with the minerals of clays, loams and organic ingredients such as alkanes, alkyl phthalates, pesticides and
Należy zwrócić uwagę, że niekontrolowane wprowadzanie nanocząstek metali i tlenków metali do środowiska jest szczególnie niebezpieczne ze względu na ich trwałość i kumulację w organizmach, ponieważ prawdopodobnie - tak samo jak metale w skali makro - nie ulegają biodegradacji, nawet gdy są dostarczane w znikomych ilościach $\mathrm{i}$ jedynie okresowo. Konieczne jest zatem prowadzenie badań na poziomie molekularnym w określaniu stabilności nanocząstek, ich rozpuszczalności oraz agregacji, które mogą wpływać na ich transformacje, toksyczność, dostępność biologiczną i trwałość w środowisku. Wśród czynników odgrywających istotną rolę w procesach zachodzących w środowisku wodnym wymienia się obecność mikroorganizmów, naturalnej materii, różnorodnych jonów nieorganicznych.

\section{Interakcje z naturalną materią organiczną}

Naturalne wody zawierają dużą liczbę cząstek o różnych rozmiarach, $w$ tym również substancję organiczną. Naturalna materia organiczna (NOM) pochodzi głównie z roślin i/lub pozostałości mikroorganizmów. W swojej pierwotnej lub chemicznie przekształconej postaci materia organiczna (MO) może migrować z gleb do hydrosfery. Transport ten jest zazwyczaj związany z opadami deszczu, które albo spływają, albo przesiąkają przez kolumnę gleby, przenosząc rozpuszczone i zawieszone cząstki NOM do strumieni, jezior i oceanów lub w głąb gruntu, zasilając wody gruntowe. Materia organiczna, która pochodzi ze źródeł lądowych, stanowi ważną część ogólnej ilości materii organicznej, szczególnie w małych, kontynentalnych zbiornikach wody. MO tworzy się również in situ w zbiornikach wodnych, czego doskonałym przykładem są tereny podmokłe, zarówno naturalne, jak i sztuczne. Bujny wzrost roślinności powoduje powstanie tam grubej warstwy napowietrzonej materii oraz korzeni, które po obumarciu pozostają w wodzie. Oszacowano, że w skali światowej ok. 10\% aktywności drobnoustrojowej w wodzie wykorzystywane jest do wytworzenia rozpuszczonej materii organicznej [16].

Należy zaznaczyć, że oprócz źródeł naturalnych, również i źródła antropogeniczne dostarczają specyficznych związków organicznych, takich jak substancje stosowane w rolnictwie, preparaty lecznicze, produkty lub odpady z procesów przemysłowych, odcieki ze składowisk odpadów, ścieki zawierające fenole, substancje powierzchniowo czynne, wielopierścieniowe węglowodory aromatyczne, chlorowane związki organiczne oraz związki ropopochodne [17].

Cząstki materii organicznej dzieli się na trzy klasy lub kategorie:

I. Kwasy fulwowe (KF) - rozpuszczalne w wodzie w szerokim zakresie $\mathrm{pH}$.

II. Kwasy huminowe $(\mathrm{KH})$ - frakcja humusu, która jest nierozpuszczalna w wodzie w środowisku silnie kwasowym $(\mathrm{pH} 2)$, ale rozpuszczalna w wyższych zakresach $\mathrm{pH}$.

III. Huminy $(\mathrm{Hu})$ - nierozpuszczalne $w$ wodzie w całym zakresie $\mathrm{pH}$ [18].

Substancje humusowe (SH), czyli złożone związki chemiczne wchodzące w skład tzw. humusu, są częścią zawiesiny [19-20].

Ważną cechą substancji humusowych jest ich potencjał do tworzenia rozpuszczalnych oraz nierozpuszczalnych wodnych kompleksów z jonami metali, tlenkami metali, minerałami lub wo- 
other. The interactions between humic substances and metal ions describe the reactions of ion exchange, surface adsorption, chelation, binding, coagulation and peptisation. The main participants in the metal binding reactions are carboxyl $-\mathrm{COOH}$ and hydroxy groups $-\mathrm{OH}$. Carboxyl groups react in lower $\mathrm{pH}$ values, while hydroxy groups in neutral and alkalic $\mathrm{pH}$ ranges [21]. Research results indicate that the humus' ability to bind metals is influenced by salt concentration. When the salinity is high, e.g. in a marine environment, this process is difficult [22]. However, this kind of phenomenon is not identical for all metal cations. For interactions of $\mathrm{HS}$ with some metals, e.g. Fe, $\mathrm{Al}, \mathrm{Mn}, \mathrm{Zn}, \mathrm{Cu}$, various types of complexes were found to exist. Fulvic acids contain carboxyl groups with different acidic properties and different affinities with metal ions. They have greater metal complexation capabilities than humin acids. Irving-Williams developed a series of relative stabilities of complexes of various metals with $\mathrm{HS}$, in which the metals are ordered in the following way: $\mathrm{Pb}^{2+}>\mathrm{Cu}^{2+}>$ $\mathrm{Ni}^{2+}>\mathrm{Co}^{2+}>\mathrm{Zn}^{2+}>\mathrm{Cd}^{2+}>\mathrm{Fe}^{2+}>\mathrm{Mn}^{2+}>\mathrm{Mg}^{2+}$. Van Dijk created a similar series for metal - humic acid complexes with $\mathrm{pH}=5: \mathrm{Zn}^{2}+>$ $\mathrm{Fe}^{2+}>\mathrm{Ni}^{v}>\mathrm{Co}^{2+}>\mathrm{Mn}^{2+}>\mathrm{Mg}^{2+}>\mathrm{Ca}^{2+}>\mathrm{Ba}^{2+}[9]$.

Suspended particulate matter (SPM) plays an important role in the transport of pollutants. The suspension is composed of organic and inorganic substances, i.e. particles with a more or less complicated structure, qualitative and quantitative composition, as well as different physico-chemical properties. However, only the fraction with a diameter $<1 \mu \mathrm{m}$ remains suspended and favours the transport of substances adsorbed on its surface across long distances [9].

In order to be able to describe the transport of nanoparticles of metal and metal oxides in the environment and, consequently, to determine their impact on organisms, it is necessary to understand the aggregation processes of NPMOs and to develop a quantitative model of aggregation for those nanoparticles. Studies conducted in several different research centres have shown that natural organic matter and the presence of microbes may lead to the transformation of nanocompounds and cause their mobilisation in the environment, which may have harmful effects on organisms [23-27].

A number of studies also confirm the significant impact of the presence and concentration of NOM on the aggregation processes and stability of nanoparticles of metal and metal oxides in aquatic ecosystems [28-34]. NOM may apply a negative charge to the surface of nanoparticles, thereby increasing their surface potential. This leads to the formation of an energy barrier between nanoparticles. As a result, the presence of NOM stabilises or at least reduces nanoparticle aggregation [25], [32], [35-36]. However, some results show that natural organic matter may delay aggregation [36] and other findings even indicate disaggregation as the result of the presence of NOM in the water [37].

Labille and Brant [38] attempted to find the available information on potential changes to the properties and behaviour of the produced nanoparticles in various water solutions. They presented general reactions occurring at the nanoparticle-water interface or between nanoparticles. The conclusion was that water systems were a potential carrier for nanoparticles introduced into the natural environment and their presence in water posed dorotlenkami. SH wykazują także zdolność do interakcji z minerałami glin, iłów oraz składnikami organicznymi, takimi jak alkany, ftalany alkilowe, pestycydy i inne. Interakcje pomiędzy substancjami humusowymi i jonami metali opisują reakcje wymiany jonowej, adsorpcji powierzchniowej, chelatowania, przyłączania, koagulacji i peptyzacji. W reakcjach przyłączania metali biorą udział głównie grupy karboksylowe - $\mathrm{COOH}$ oraz hydroksylowe $-\mathrm{OH}$. Grupy karboksylowe reagują w niższych przedziałach odczynu, grupy hydroksylowe w obojętnych i alkalicznych zakresach pH [21]. Wyniki badań wskazują, że na zdolność przyłączania metali przez humusy ma wpływ stężenie soli. Przy wysokim stopniu zasolenia, np. w środowisku morskim, proces ten jest utrudniony [22]. Jednak zjawisko tego typu nie jest jednakowe dla wszystkich kationów metali. W przypadku interakcji SH z niektórymi metalami, np. Fe, Al, Mn, Zn, $\mathrm{Cu}$, stwierdzono istnienie różnego typu kompleksów. W kwasach fulwowych istnieją grupy karboksylowe o różnych własnościach kwasowych i różnym powinowactwie do jonów metali. Posiadają one większą zdolność kompleksowania metali od kwasów huminowych. Irving-Williams opracował szereg trwałości kompleksów różnych metali z SH, w którym metale uszeregowane są następująco: $\mathrm{Pb}^{2+}>\mathrm{Cu}^{2+}>$ $\mathrm{Ni}^{2+}>\mathrm{Co}^{2+}>\mathrm{Zn}^{2+}>\mathrm{Cd}^{2+}>\mathrm{Fe}^{2+}>\mathrm{Mn}^{2+}>\mathrm{Mg}^{2+}$. Van Dijk stworzył podobny szereg dla kompleksów metal - kwas humusowy przy wartości $\mathrm{pH}$ : $: \mathrm{Zn}^{2+}>\mathrm{Fe}^{2+}>\mathrm{Ni}^{2+}>\mathrm{Co}^{2+}>\mathrm{Mn}^{2+}>\mathrm{Mg}^{2+}>\mathrm{Ca}^{2+}>\mathrm{Ba}^{2+}[9]$.

Zawiesina odgrywa ważną rolę $\mathrm{w}$ transporcie zanieczyszczeń. Składa się z substancji organicznych i nieorganicznych, czyli cząstek o mniej lub bardziej skomplikowanej budowie, składzie jakościowym i ilościowym, a także o odmiennych właściwościach fizyko-chemicznych. Jednakże tylko frakcja o średnicy < $1 \mu \mathrm{m}$ pozostaje w stanie zawieszonym i sprzyja transportowi substancji zaadsorbowanych na jej powierzchni na dalekie odległości [9].

Charakterystyka transportu nanocząstek metali i tlenków metali w środowisku i - co za tym idzie - określenie ich wpływu na organizmy wymaga zrozumienia procesów agregacji NPMOs oraz opracowania modelu ilościowego agregacji tych nanocząstek. Prowadzone w różnych ośrodkach badania pokazują, że naturalna materia organiczna oraz obecność mikroorganizmów może prowadzić do przemiany nanozwiązków i spowodować ich mobilizację w środowisku, co w konsekwencji może mieć szkodliwy wpływ na organizmy [23-27].

Wyniki wielu badań potwierdzają także znaczący wpływ obecności i stężenia NOM na procesy agregacji i stabilności nanocząstek metali i tlenków metali w ekosystemach wodnych [28-34]. NOM może ujemnie naładować powierzchnię nanocząstek i tym samym zwiększyć ich potencjał powierzchniowy. Prowadzi to do wytworzenia bariery energetycznej między nanocząsteczkami. W konsekwencji obecność NOM stabilizuje lub przynajmniej zmniejsza agregację nanocząstek [25], [32], [3536]. Niektóre wyniki dowodzą jednak, że naturalna materia organiczna może opóźnić agregację [36], a inne wskazują nawet na dezagregację na skutek obecności NOM w wodzie [37].

Labille i Brant [38] podjęli próbę zebrania dostępnych informacji w zakresie ewentualnych zmian właściwości i zachowania wyprodukowanych nanocząstek $w$ różnych roztworach wodnych. W swojej pracy przedstawili ogólne reakcje występujące na styku nanocząstka - woda lub pomiędzy nanocząstkami. Stwierdzili, że systemy wodne są potencjalnym nośnikiem na- 
a risk of dysfunction development in water organisms and humans [38]. On the other hand, Gottschalk et al. found that surface waters acted primarily as a dispersive medium, whereas bottom sediments and soil could accumulate a large amount of nanoparticles [39].

The impact of nanoparticles on the environment has been studied not only in terms of interactions with NOM [19], [25], [32], [35], [40-48] but also in the context of the possibility of aggregation [23], [38], [40-41], [49-50], the impact of $\mathrm{pH}$ on nanoparticle transformation [19], [51-55] and the presence and concentration of various inorganic ions [25], [42], [56-57].

Bian et al. [54] focused on determining the stability of $\mathrm{ZnO}$ nanoparticles with a diameter of $4 \pm 1 \mathrm{~nm}$ in water solutions with variable $\mathrm{pH}$ values and ionic strength as well as in the presence of humic acids. The study results show that ionic strength, $\mathrm{pH}$ and adsorption of humic acids influence the aggregation of $\mathrm{ZnO}$ NPs in water solutions. Measurements of nanoparticle solubility show that zinc ions are released to the water phase depending on the solution's $\mathrm{pH}$. In addition, the presence of HA may contribute to an increase in the concentration of the $\mathrm{Zn}^{2+}$ form. A comparison of solubility of $\mathrm{ZnO} N P s$ with various nanoparticle diameters $(15-240 \mathrm{~nm})$ shows that the smallest nanoparticles are more soluble [54]. Literature data also indicate that, depending on $\mathrm{pH}, \mathrm{ZnO}$ NPs in an aquatic environment not only dissociate $\mathrm{Zn}^{2+}$ ions, but also undergo transformation to $\mathrm{Zn}(\mathrm{OH})_{2}$ [58].

Liu et al. [56] noticed that in the presence of $\mathrm{CaCl}_{2}$, the formation of $\mathrm{ZnO} N P$ aggregates was more effective than for $\mathrm{NaCl}$ and $\mathrm{KCl}$ [56]. Li and Chen [42] and Lin et al. [29] reached similar conclusions, having found that the aggregation speed of $\mathrm{CeO}_{2}$ and $\mathrm{TiO}_{2}$ nanoparticles significantly rises with the increase in the concentration of $\mathrm{CaCl}_{2}, \mathrm{KCl}$ and $\mathrm{NaCl}$ [29], [42] salts. The presence of humic acids was also significant. Regardless of the concentration, the presence of $\mathrm{HA}$ in a $\mathrm{KCl}$ solution slowed down the kinetics of aggregation of $\mathrm{CeO}_{2}$. For a low concentration of $\mathrm{CaCl}_{2}$, HA slowed down aggregation and accelerated it as the concentration of the salt increased [42].

Liu et al. [57] proved HA have an impact on the process of aggregation of silicon nanoparticles with $\mathrm{Ca}^{2+}$, and thereby their transport in an aquatic environment. The scientists observed that silicon nanoparticles were subject to aggregation in a $0.1 \mathrm{M} \mathrm{CaCl}_{2}$ solution. The deposition rate increased with a $0.1 \mathrm{M}$ increase in $\mathrm{Ca}^{2+}$ concentration and then remained at a constant level with a further increase in calcium ion concentration. Increased aggregation of silicon nanoparticles in the presence of $\mathrm{HA}$ was attributed to the binding of $\left(\mathrm{KH}-\mathrm{Ca}^{2+}\right)$ in the solution with $\mathrm{Ca}^{2+}$. Furthermore, with the same ionic strength, the deposition rate was higher in the presence of $\mathrm{HA}$ than in its absence. An analysis using TEM indicated the presence of a cluster of gel formed as a result of complexation between $\mathrm{Ca}^{2+}$ and $\mathrm{KH}$. The study results also indicate that carbon and oxygen are present in both silicon aggregates and in the area of bridges, which confirms that HA particles played a significant role within the particles and between silicon aggregates [57].

Zhang et al. [25] determined the impact of NOM and $\mathrm{Ca}^{2+}$ on the stability of nanoparticles of such metal oxides as $\mathrm{ZnO}$, $\mathrm{NiO}, \mathrm{TiO}_{2}, \mathrm{Fe}_{2} \mathrm{O}_{3}$ and $\mathrm{SiO}_{2}$. The obtained results led the researchers to the conclusion that a low concentration of electrolytes $(0.01 \mathrm{M} \mathrm{KCl})$ in an aquatic environment may cause their aggrega- nocząstek wprowadzanych do środowiska naturalnego, a ich obecność w wodzie stwarza ryzyko pojawiania się dysfunkcji w organizmach wodnych, a także u ludzi [38]. Z kolei Gottschalk i in. stwierdzają, że wody powierzchniowe działają głównie jako środowisko dyspersyjne, podczas gdy osady denne oraz gleba są w stanie zgromadzić duże ilości nanocząstek [39].

Oddziaływanie nanocząstek na środowisko badano nie tylko pod kątem interakcji z NOM [19], [25], [32], [35], [40-48], ale także pod względem m.in. możliwości występowania agregacji [23], [38], [40-41], [49-50], wpływu pH na przemiany nanocząstek [19], [51-55] oraz obecności i stężenia różnych jonów nieorganicznych [25], [42], [56-57].

Bian i in. [54] skupili się na określeniu stabilności nanocząstek ZnO o średnicy $4 \pm 1 \mathrm{~nm}$ w roztworach wodnych, przy zmiennych wartościach pH i siły jonowej oraz w obecności kwasów humusowych. Wyniki badań pokazują, że siła jonowa, pH i adsorpcja kwasów humusowych mają wpływ na agregację ZnO NPs w roztworach wodnych. Pomiary rozpuszczalności nanocząstek wykazują, że jony cynku są uwalniane do fazy wodnej w zależności od pH roztworu. Co więcej, obecność KH może wpływać na zwiększenie stężenia formy $\mathrm{Zn}^{2+}$. Porównanie rozpuszczalności ZnO NPs o różnych średnicach nanocząstek (15-240 nm) pokazuje, że najmniejsze nanocząstki rozpuszczają się łatwiej [54]. Doniesienia literaturowe wskazują także, że ZnO NPs w środowisku wodnym - w zależności od pH - nie tylko dysocjują na jony $\mathrm{Zn}^{2+}$, ale także ulegają przemianie do $\mathrm{Zn}(\mathrm{OH})_{2}$ [58].

Liu i in. [56] dostrzegli, że w obecności $\mathrm{CaCl}_{2}$ tworzenie agregatów ZnO NPs zachodziło skuteczniej niż przy NaCl i KCl [56]. Do podobnych wniosków doszli Li i Chen [42] oraz Lin i in. [29], którzy stwierdzili, że szybkość agregacji nanocząstek $\mathrm{CeO}_{2}$ i $\mathrm{TiO}_{2}$ wyraźnie wzrasta wraz ze wzrostem stężenia soli $\mathrm{CaCl}_{2}$, $\mathrm{KCl}, \mathrm{NaCl}$ [29], [42]. Ponadto istotna była także obecność kwasów humusowych. W roztworze $\mathrm{KCl}$, niezależnie od stężenia, obecność $\mathrm{KH}$ zmniejszała kinetykę agregacji $\mathrm{CeO}_{2}$. Z kolei przy niskim stężeniu $\mathrm{CaCl}_{2} \mathrm{KH}$ hamowały agregację, natomiast wraz ze wzrostem stężenia soli KH przyspieszały agregację [42].

Liu i in. [57] udowodnili, że istnieje wpływ KH na proces agregacji nanocząstek krzemu przy $\mathrm{Ca}^{2+}$, a tym samym ich transport w środowisku wodnym. Naukowcy zaobserwowali, że nanocząstki krzemu ulegały agregacji w roztworze $0,1 \mathrm{M} \mathrm{CaCl}_{2}$. Natomiast wydajność osadzania wzrastała wraz ze wzrostem stężenia $\mathrm{Ca}^{2+}$ o 0,1 M, a następnie utrzymywała się na stałym poziomie przy dalszym wzroście stężenia jonów wapnia. Zwiększenie agregacji nanocząstek krzemu w obecności KH zostało przypisane powstałemu połączeniu $\left(\mathrm{KH}^{-\mathrm{Ca}^{2+}}\right) \mathrm{w}$ roztworze $\mathrm{z} \mathrm{Ca}{ }^{2+}$. Ponadto przy tej samej sile jonowej wydajność osadzania była wyższa w obecności KH niż bez KH. Analiza przy użyciu TEM wykazała obecność klastra żelu powstałego na skutek kompleksowania pomiędzy $\mathrm{Ca}^{2+} \mathrm{i} \mathrm{KH}$. Wyniki badań pokazują także, że węgiel i tlen występują zarówno w agregatach krzemu, jak i w obszarze mostków, co potwierdza, że cząsteczki KH odgrywały znaczącą rolę w obrębie cząstek i między agregatami krzemowymi [57].

Zhang i in. [25] określili wpływ $\mathrm{NOM} \mathrm{i} \mathrm{Ca}^{2+}$ na stabilność nanocząstek takich tlenków metali jak $\mathrm{ZnO}, \mathrm{NiO}, \mathrm{TiO}_{2}, \mathrm{Fe}_{2} \mathrm{O}_{3}$ i $\mathrm{SiO}_{2}$. Na podstawie otrzymanych wyników stwierdzili, że w środowi- 
tion. However, after adding $1 \mathrm{mg} \cdot \mathrm{dm}^{-3}$ of NOM, the negative surface charge of nanoparticles significantly increases, which means that their tendency to aggregate is reduced. On the other hand, a negative charge caused by NOM may be neutralised by calcium cations which, even at concentrations of $0,04-0,06 \mathrm{M} \mathrm{Ca}^{2+}$, cause the aggregation of nanoparticles covered in NOM [25].

Humin acids ( $\mathrm{HnA}$ ) and fulvic acids (FA) have a number of functional groups which facilitates their complexation with metal ions and interaction with nanocompounds. These interactions may not only change the behaviour of nanosubstances in the environment but also influence the capacity of nanocompounds to remove and transport heavy metals [59]. Zhu et al. 2014 [60] and Thio et al. 2011 [32] found that HA may contribute to the stability of $\mathrm{TiO}_{2}$ NPs by charge neutralisation, bridging effects, steric hindrance and electrostatic and steric repulsion between particles [32], [60]. Aggregation was initiated by positive $\mathrm{HA}$ only when the $\mathrm{pH}$ was lower than the point of zero charge for $\mathrm{TiO}_{2} \mathrm{NPs}$, i.e. $\mathrm{pH}_{\mathrm{Pzc}} 6$, due to a reduction in the zeta potential of $\mathrm{TiO}_{2} \mathrm{NPs}$ by HA. At pH 4 and $\mathrm{HA}$ concentration of $0.094 \mathrm{mg} \cdot \mathrm{dm}^{-3}$, the zeta potential of $\mathrm{TiO}_{2} \mathrm{NPs}$ was close to 0 , while $\mathrm{TiO}_{2} \mathrm{NPs}$ reached maximum aggregation. A higher HA concentration caused the negative charge of $\mathrm{TiO}_{2} \mathrm{NP}$ surface and hindered nanoparticle aggregation. For the solution with a pH of 5.8, the presence of HA led to an increase in the negative zeta potential of $\mathrm{TiO}_{2} \mathrm{NPs}$. In such conditions, the stability of nanoparticles increased due to electrostatic repulsion and steric hindrance. When $\mathrm{pH}$ is higher than $\mathrm{pH}_{\mathrm{PzC}}$ (the $\mathrm{pH}$ value at the point of zero charge, $\mathrm{PZC}$ ), the zeta potential of $\mathrm{TiO}_{2} \mathrm{NPs}$ is high $(\sim 40 \mathrm{mV})$ and stays virtually the same as the concentration of HA increases [60].

The impact of ionic strength and the presence of humic acids of the Suwannee River on the aggregation and stability of ZnO NPs was also studied by Han et al. [61]. The ZnO nanoparticles were obtained by various methods and were characterised by different grain sizes and surfaces. The level of aggregation in solutions in the absence of HA for both types of $\mathrm{ZnO}$ nanoparticles rose with the increase in ionic strength, in accordance with the DLVO theory. In solutions containing HA ( 1 and $\left.5 \mathrm{mg} \cdot \mathrm{dm}^{-3}\right)$ the aggregation of both forms of ZnO NPs differed from the DLVO theory, which was caused by repulsive forces. The study results show that the presence of HA determines the solubility of nanoparticles. However, at pH 9 and 6 the solubility of ZnO NPs with larger grains and smaller surface was greater than in the case of ZnO NPs with smaller grains and larger surface. This was probably caused by the differences in the rate of adsorption of HA between the individual types of ZnO NPs. Lower hydrophilicity and stronger electrostatic attraction between humic acid and ZnO NPs with larger grains determined the positive zeta potential of $\mathrm{ZnO}$ nanoparticles [61].

A $1 \mathrm{mg} \cdot \mathrm{dm}^{-3}$ increase in NOM concentration in the solution significantly increases the negative surface charge of nanoparticles [25]. ZnO NP aggregation may be considerably reduced where zinc oxide nanoparticles primarily interact with organic matter and not between each other. In addition, electrostatic interactions effectively contribute to reducing the amount of retained ZnO NPs in a porous medium [41], [45]. sku wodnym niskie stężenie elektrolitów $(0,01 \mathrm{M} \mathrm{KCl})$ może doprowadzić do ich agregacji. Jednakże po dodaniu $1 \mathrm{mg} \cdot \mathrm{dm}^{-3}$ NOM znacznie zwiększa się ujemny ładunek powierzchniowy nanocząstek, a zatem ich skłonność do agregacji jest zredukowana. Z drugiej strony, ujemny ładunek powodowany przez NOM może być neutralizowany przez kationy wapnia i już przy stężeniu od 0,04-0,06 $\mathrm{M} \mathrm{Ca}^{2+}$ wywołują agregację nanocząstek pokrytych NOM [25].

Ze względu na fakt, iż kwasy huminowe $(\mathrm{KHu}) \mathrm{i}$ kwasy fulwowe (KF) mają wiele grup funkcyjnych, możliwe jest ich kompleksowanie z jonami metali i oddziaływanie z nanozwiązkami. Te interakcje mogą nie tylko zmienić zachowanie nanosubstancji w środowisku, ale także wpłynąć na możliwość usuwania i transport metali ciężkich przez nanozwiązki [59]. Zhu i in. [60] oraz Thio i in. [32] ustalili, że KH może wpływać na stabilność $\mathrm{TiO}_{2} \mathrm{NPs}$ poprzez neutralizację ładunku, efekty mostkowania, przeszkodę steryczną oraz odpychanie elektrostatyczne i steryczne pomiędzy cząsteczkami [32], [60]. Agregacja była inicjowana przez dodanie $\mathrm{KH}$ tylko wtedy, gdy $\mathrm{pH}$ było niższe niż punkt zerowego ładunku dla $\mathrm{TiO}_{2} \mathrm{NPs}$, tj. $\mathrm{pH}_{\mathrm{Pzc}} 6$, ze względu na zmniejszenie potencjału Zeta TiO2 NPs przez KH. Przy pH 4 i stężeniu KH wynoszącym $0,094 \mathrm{mg} \cdot \mathrm{dm}^{-3}$ potencjał zeta $\mathrm{TiO}_{2} \mathrm{NPs}$ był bliski 0, wówczas $\mathrm{TiO}_{2} \mathrm{NPs}$ osiągnęły maksimum agregacji. Wyższe stężenie $\mathrm{KH}$ spowodowało ujemne naładowanie powierzchni $\mathrm{TiO}_{2} \mathrm{NPs}$ i utrudniło agregację nanocząstek. W przypadku roztworu o pH 5,8 obecność KH spowodowała zwiększenie ujemnego potencjału Zeta $\mathrm{TiO}_{2} \mathrm{NPs}$. W takich warunkach nastąpiło zwiększenie stabilności nanocząstek poprzez odpychanie elektrostatyczne i przeszkodę

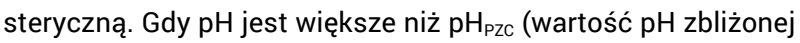
do punktu zerowego ładunku, $\mathrm{PZC}$ ), potencjał zeta $\mathrm{TiO}_{2} \mathrm{NPs}$ jest wysoki ( $40 \mathrm{mV})$ i prawie nie zmienia się wraz ze wzrostem stężenia $\mathrm{KH}[60]$.

Wpływ siły jonowej i obecności kwasów humusowych Suwannee River na agregację i stabilność ZnO NPs był badany także przez Han i innych [61], przy czym nanocząstki ZnO otrzymywane różnymi metodami charakteryzowały się różną wielkością ziaren i różną powierzchnią. Stopień agregacji w roztworach bez obecności KH dla obu typów nanocząstek ZnO wzrastał wraz ze wzrostem siły jonowej, zgodnie z klasyczną teorią DLVO. Natomiast w roztworach zawierających $\mathrm{KH}\left(1\right.$ i $5 \mathrm{mg} \cdot \mathrm{dm}^{-3}$ ) agregacja obu form ZnO NPs różniła się od teorii DLVO, co było spowodowane siłami odpychającymi. Wyniki badań pokazują, że obecność $\mathrm{KH}$ determinuje rozpuszczalność nanocząstek. Jednakże przy pH 9 i 6 rozpuszczalność ZnO NPs - charakteryzujących się większymi ziarnami i mniejsza powierzchnią - odbywała się szybciej niż w przypadku ZnO NPs o mniejszych ziarnach, ale większej powierzchni. Najprawdopodobniej było to spowodowane różnicą w stopniu adsorpcji KH na poszczególnych typach ZnO NPs. Mniejsza hydrofilowość i silniejsze przyciąganie elektrostatyczne pomiędzy kwasem humusowym i ZnO NPs o większych ziarnach determinował dodatni potencjał zeta tych nanocząstek ZnO [61].

Wzrost stężenia NOM o $1 \mathrm{mg} \cdot \mathrm{dm}^{-3} \mathrm{w}$ roztworze znacznie zwiększa ujemny ładunek powierzchniowy nanocząstek [25]. Agregacja ZnO NPs może być znacznie zmniejszona, gdyż nanocząstki tlenku cynku oddziaływają przede wszystkim z materią organiczną, a nie między sobą. Co więcej - oddziaływania elek- 
Chen et al. [46] reported increased mobility of TiO2 NPs in columns with sand in an acidic environment ( $\mathrm{pH}$ 5.7) even at low $\mathrm{HA}$ concentrations of $1 \mathrm{mg} \cdot \mathrm{dm}^{-3}$. As for an alkaline $\mathrm{pH}(\mathrm{pH} 9)$, the mobility of $\mathrm{TiO}_{2} \mathrm{NPs}$ is limited regardless of HA concentration. According to Chen et al., natural organic matter and $\mathrm{pH}$ of the solution are probably the key factors affecting the stability and mobility of $\mathrm{TiO}_{2}$ NPs in a natural aquatic environment [46]. Luo et al., 2018 [62] also proved that humic acid has a higher hydrophobicity than fulvic acid and is more readily absorbed from water to the surface of the $\mathrm{TiO}_{2}$ [62] nanoparticles.

Many scientific centres are carrying out studies of the relationship between $\mathrm{pH}$ and $\mathrm{HA}$ adsorption on nanoparticles and their impact on the surface charge and aggregation of nanoparticles. Scientists have clearly determined that an increase in nanoparticle concentrations results in higher aggregation, particularly at $\mathrm{pH}$ values at the point of zero charge [99], [106]. Large aggregates form close to that value, while stable structures are present at $\mathrm{pHs}$ higher than $\mathrm{pH}_{\mathrm{pzc}}$. With the increase of humic acid concentration, the isoelectric point appears at lower $\mathrm{pH}$ values. In an acidic environment, trace quantities of humic acids are adsorbed on the surface of $\mathrm{Fe}_{3} \mathrm{O}_{4}$ magnetite nanoparticles as oppositely charged structures. This makes systems become more unstable due to heterocoagulation. Humic-acid-coated magnetite particles create a stable colloidal suspension [51]. The results of studies by Baaloush indicate that the aggregation of iron(II) oxide is increased for $\mathrm{pH}$ values at the point of zero charge (PZC), which is 7.1 for iron nanoparticles. Humic acids at the concentration of $100 \mathrm{mg} \cdot \mathrm{dm}^{-3}$ make the maximum level of nanoparticle aggregation move towards lower $\mathrm{pH}$ values, while lower HA concentration, at about $10 \mathrm{mg} \cdot \mathrm{dm}^{-3}$, has negligible or no influence on aggregation. Disaggregation was caused by an increase in the surface charge triggered by the sorption of HA particles on the nanoparticle surface. The degree of disaggregation increased with the concentration of humic acids and decreased over time. The formation of small $(170 \mathrm{~nm}) \mathrm{HA}$ coated aggregates of iron oxide nanoparticles confirms the role of NOM in the process of disaggregation and indicates that nanoparticles may imitate the behaviour of natural colloids [37].

It should be emphasised that under natural conditions a large part of iron, including Fe NPs, is bound to organic matter, including humic and fulvic acids, which have the greatest capacity to form complexes with iron. All $\mathrm{Fe}^{2+}$ compounds are generally unstable and mobile. Stable forms include $\mathrm{Fe}^{3+}$ compounds such as oxides, hydroxides, phosphates and carbonates, as well as sulphates [63].

Ghosh et al. [19] found that the behaviour of $\mathrm{Al}_{2} \mathrm{O}_{3}$ nanoparticles is considerably influenced by the $\mathrm{pH}$ of the solution and natural organic matter. HA may stabilise the colloidal system of $\mathrm{Al}_{2} \mathrm{O}_{3} \mathrm{NPs}$, while under acidic conditions $\mathrm{HA}$ reduce colloidal stability. The surface charge of NPs is reduced with the increase in $\mathrm{pH}$ and addition of HA. Nanoparticles have a tendency to aggregate when $\mathrm{pH}$ is close to $\mathrm{pH}_{\mathrm{pzc}}$. In such conditions, the forces of Van der Waals electrostatic attraction dominate over electrostatic repulsion. Ghosh also found that the hydrophobic nature of HA particles has a strong impact on the aggregation of colloidal NPs [19]. trostatyczne skutecznie przyczyniają się do zmniejszenia ilości zatrzymanych ZnO NPs w ośrodku porowatym [41], [45].

Chen i in. [46] donoszą o zwiększonej mobilności Ti02 NPs w kolumnach z piaskiem w środowisku kwaśnym $(\mathrm{pH} 5,7)$ nawet przy niskim stężeniu $\mathrm{KH}$ wynoszącym $1 \mathrm{mg} \cdot \mathrm{dm}^{-3}$. Natomiast przy zasadowym pH (pH 9), niezależnie od stężenia $\mathrm{KH}$, mobilność $\mathrm{TiO}_{2}$ NPs jest ograniczona. Według Chen i innych naturalna materia organiczna i pH roztworu są prawdopodobnie kluczowymi czynnikami wpływającymi na stabilność i mobilność $\mathrm{TiO}_{2} \mathrm{NPs}$ w naturalnym środowisku wodnym [46]. Luo i in. [62] dowiedli, że kwas humusowy wykazuje silniejszą hydrofobowość niż kwas fulwowy i łatwiej absorbuje się z wody na powierzchnię nanocząstek $\mathrm{TiO}_{2}$ [62].

W wielu ośrodkach naukowych prowadzone są badania dotyczące zależności między pH a adsorpcją KH na nanocząstkach oraz ich wpływu na ładunek powierzchniowy i agregację nanocząstek. Naukowcy jednoznacznie stwierdzają, że wzrost stężenia nanocząstek zwiększa ich agregację, zwłaszcza przy wartości pH zbliżonej do punktu zerowego ładunku [99], [106]. Blisko tej wartości pH tworzą się duże agregaty, natomiast stabilne struktury istnieją przy pH wyższym od pH $\mathrm{P}_{\mathrm{Pzc}}$. W przypadku zwiększenia stężenia kwasów humusowych punkt izoelektryczny przypada przy mniejszych wartościach pH. W środowisku kwaśnym śladowe ilości kwasów humusowych są adsorbowane na powierzchni nanocząstek magnetytu $\mathrm{Fe}_{3} \mathrm{O}_{4}$ jako przeciwnie naładowane struktury. Wówczas układy stają się bardziej niestabilne ze względu na heterokoagulację. Natomiast cząstki magnetytu powleczone kwasami humusowymi tworzą stabilną zawiesinę koloidalną [51]. Wyniki badań Baalousha wskazują, że agregacja tlenku żelaza(II) zostaje zwiększona przy wartości pH zbliżonej do punktu zerowego ładunku (PZC), który dla nanocząstek żelaza wynosi 7,1 . Kwasy humusowe przy stężeniu $100 \mathrm{mg} \cdot \mathrm{dm}^{-3}$ powodują, że maksymalny stopień agregacji nanocząstek przesuwa się w kierunku niższych wartości pH, podczas gdy mniejsze stężenie $\mathrm{KH}$ - rzędu $10 \mathrm{mg} \cdot \mathrm{dm}^{-3}$ - wykazują znikomy lub zerowy wpływ na agregację. Dezagregacja spowodowana była przez zwiększenie ładunku powierzchniowego wywołanego przez sorpcję cząsteczek $\mathrm{KH}$ na powierzchni nanocząstek. Stopień dezagregacji wzrastał wraz ze wzrostem stężenia kwasów humusowych i zmniejszał się wraz z upływem czasu. Tworzenie małych agregatów $(170 \mathrm{~nm})$ nanocząstek tlenku żelaza z powłoką KH potwierdza rolę NOM w procesie dezagregacji i wskazuje, że nanocząstki mogą naśladować zachowanie naturalnych koloidów [37].

Należy zaznaczyć, że w warunkach naturalnych duża część żelaza, w tym Fe NPs, jest związana z materią organiczną, także z kwasami humusowymi i fulwowymi, których zdolności do tworzenia kompleksów z żelazem są najwyższe. Wszystkie związki $\mathrm{Fe}^{2+}$ są na ogół niestabilne i mobilne. Stabilne formy obejmują związki $\mathrm{Fe}^{3+}$, takie jak tlenki, wodorotlenki, fosforany i węglany, jak również siarczany [63].

Ghosh i in. [19] stwierdzili, że na zachowanie nanocząstek $\mathrm{Al}_{2} \mathrm{O}_{3}$ znacząco wpływa $\mathrm{pH}$ roztworu oraz naturalna materia organiczna. $\mathrm{KH}$ mogą stabilizować układ koloidalny $\mathrm{Al}_{2} \mathrm{O}_{3} \mathrm{NPs}$, natomiast w warunkach kwasowych $\mathrm{KH}$ zmniejszają trwałość koloidalną. Ładunek powierzchniowy NPs zmniejsza się wraz ze wzrostem $\mathrm{pH}$ i dodaniu KH. Nanocząstki mają tendencję do agregacji, kiedy $\mathrm{pH}$ jest bliskie $\mathrm{pH}_{\mathrm{pzc}}$. Wówczas siły przyciągania elektrostatycznego Van der Waalsa dominują nad odpychaniem elektrostatycznym. 
The results of studies conducted by Quik et al. [64] prove that particle diameter, $\mathrm{pH}$, electrical conductivity and NOM are significantly correlated with $\mathrm{CeO}_{2} \mathrm{NPs}$ in the suspension. The scientists determined the concentration and size of $\mathrm{CeO}_{2} \mathrm{NPs}$ in an algal culture medium and deionised water in the presence of various concentrations of organic matter sourced from two different rivers, the Suwannee and the Bihain. Suspension in the water sample collected from the Suwannee River contained 6\% HA and $60 \% \mathrm{FA}$, while the material collected from the Bihain River was composed of $19 \% \mathrm{HA}$ and $45 \% \mathrm{FA}$. In the presence of NOM, after $12 \mathrm{~h}$ of observation, as much as up to $88 \%$ of the initially added $\mathrm{CeO}_{2} \mathrm{NPs}$ remained suspended in deionised water and $41 \%$ in the culture medium [64].

SEM studies carried out by Manoharan et al. [47] demonstrated that under the influence of humic acid interaction with Ag NPs, these nanoparticles change their physical and chemical properties. The scientists suggested a KH-Ag NP interaction mechanism, which demonstrates that nanoparticles are subject to transformation in the environment. This means that humic compounds may function both as stabilising substances and as reducing substances, determining the chemical properties of new molecular entities. Moreover, the capacity of humic substances to bond metal ions is relatively higher in comparison to their capacity to form complexes with metals [47].

Yang et al. [35] focused on determining the $\mathrm{HA}$ interaction with the nanoparticles of four metal oxides, i.e. $\mathrm{TiO}_{2}, \mathrm{SiO}_{2}, \mathrm{Al}_{2} \mathrm{O}_{3}$ and $\mathrm{ZnO}$. It was observed that the process of $\mathrm{HA}$ adsorption took place on $\mathrm{TiO}_{2}, \mathrm{Al}_{2} \mathrm{O}_{3}$ and $\mathrm{ZnO}$ nanoparticles, while it was not observed on $\mathrm{SiO}_{2} \mathrm{NPs}$. The adsorption maxima of humic acids on oxide nanoparticles were limited by the surface area of those nanoparticles. The phenyl group $-\mathrm{OH}$ and $-\mathrm{COOH}$ characteristic of humic acids were responsible for the exchange of the ligand with, $\mathrm{TiO}_{2} \mathrm{NPs}$ and $\mathrm{ZnO} \mathrm{NPs}$, respectively. In the case of $\mathrm{n}-\mathrm{Al}_{2} \mathrm{O}_{3}$ a strong interaction was observed between the $-\mathrm{COOH}$, phenyl $-\mathrm{OH}$ and alcohol $-\mathrm{OH}$ groups and the surface of the aluminum oxide nanoparticle. The adsorption of humic acids leads to a reduction in metal oxide nanoparticle micropore area and zeta potential, which is why metal oxide nanoparticles bound with humic acids may disperse and suspend more easily and are more stable in the solution than free nanoparticles [35]. Such processes affect the change of properties of nanoparticles and their migration capabilities in an aquatic environment.

Lopes et al. [65] found that the process of $\mathrm{n}-\mathrm{ZnO}$ dissolution is shaped not only by the size and structure of particles, and the method of synthesis of nanoparticles, which also determine their physicochemical properties, but also by the medium, in which this process takes place. They also observed that $\mathrm{ZnO}$ in both macro and nano scales were an identical source of zinc ions in the environment. The scientists also proved that in the course of several months in waters simulating natural conditions $\mathrm{ZnO}$ nanoparticles change their size and shape, and that the toxicity of $\mathrm{ZnO}$ NPs should be explained by their dissolution and the toxicity of the $\mathrm{Zn}^{2+}$ ions being formed [65].

Due to the ubiquity of humic substances, metal nanoparticles released into the environment might bind with $\mathrm{OM}$ and become coated in HA/FA. This process might lead to change in the
Ghosh stwierdził także, że hydrofobowy charakter cząsteczki KH silnie wpływa na agregację koloidalnych NPs [19].

Wyniki badań przeprowadzonych przez Quik i innych [64] dowodzą, że średnica cząstek, pH przewodność elektryczna i NOM wykazują znaczną korelację z $\mathrm{CeO}_{2} \mathrm{NPs}$ w zawiesinie. Naukowcy określili stężenie i wielkość $\mathrm{CeO}_{2} \mathrm{NPs}$ w pożywce hodowlanej glonów i dejonizowanej wodzie, w obecności różnych stężeń materii organicznej pochodzącej z dwóch różnych rzek Suwannee i Bihain. Zawiesina w próbce wody pobranej z rzeki Suwannee zawierała $6 \% \mathrm{KH}$ i $60 \% \mathrm{KF}$, podczas gdy materiał pobrany z rzeki Bihain składał się z 19\% KH i 45\% KF. W obecności NOM, po $12 \mathrm{~h}$ obserwacji aż do $88 \%$ początkowo dodanych $\mathrm{CeO}_{2} \mathrm{NPs}$ pozostawało zawieszonych w wodzie dejonizowanej oraz $41 \%$ w pożywce hodowlanej [64].

Badania SEM wykonane przez Manoharan i in. [47] wykazały, że pod wpływem interakcji kwasów humusowych z Ag NPs nanocząstki te zmieniają swoje właściwości fizyczne i chemiczne. Naukowcy zaproponowali mechanizm oddziaływania KH-Ag NPs, który przedstawia, że nanocząstki ulegają transformacji w środowisku. To znaczy, że związki humusowe mogą działać zarówno jako substancje stabilizujące, jak i redukujące, determinujące właściwości chemiczne nowych indywiduów. Co więcej zdolność substancji humusowych do wiązania jonu metalu jest stosunkowo wyższa w porównaniu ze zdolnością do tworzenia kompleksów z metalami [47].

Yang i in. [35] skupili się na określeniu interakcji $\mathrm{KH}$ z nanocząstkami czterech tlenków metali, to jest $\mathrm{TiO}_{2}, \mathrm{SiO}_{2}, \mathrm{Al}_{2} \mathrm{O}_{3}$ i ZnO. Zaobserwowano, że proces adsorpcji $\mathrm{KH}$ odbywa się na nanocząstkach $\mathrm{TiO}_{2}, \mathrm{Al}_{2} \mathrm{O}_{3}$ i $\mathrm{ZnO}$, natomiast nie zauważono go na $\mathrm{SiO}_{2}$ NPs. Maxima adsorpcji kwasów humusowych na nanocząstkach tlenków były ograniczone przez pole powierzchni tych nanocząstek. Charakterystyczne dla kwasów humusowych grupy fenolowa $-\mathrm{OH} \mathrm{i}$ - $\mathrm{COOH}$ były odpowiedzialne za wymianę ligandu z - odpowiednio - TiO2 NPs i ZnO NPs. Natomiast w przypadku n- $\mathrm{Al}_{2} \mathrm{O}_{3}$ zaobserwowano silną interakcję grupy $-\mathrm{COOH}$, fenolowej $-\mathrm{OH}$ i alkoholowej $-\mathrm{OH}$ z powierzchnią nanocząstki tlenku glinu. Poprzez adsorpcję kwasów humusowych zmniejsza się powierzchnia mikroporów nanocząstek tlenków metali oraz potencjał zeta nanocząstek tlenków metali, dlatego też nanocząstki tlenków metali powiązane z kwasami humusowymi mogą łatwiej ulec rozproszeniu, zawieszeniu i są bardziej stabilne w roztworze od nanocząstek wolnych [35]. Takie procesy wpływają na zmianę właściwości nanocząstek oraz ich możliwość migracji w środowisku wodnym.

Lopes $\mathrm{i}$ in. [65] stwierdzili, że proces rozpuszczania n-ZnO jest uwarunkowany nie tylko wielkością cząstek, strukturą, metodą syntezy nanocząstek, które determinują także ich właściwości fizykochemiczne, ale także medium, w którym proces ten zachodzi. Zaobserwowali ponadto, że zarówno ZnO w skali makro, jak i nano, są takim samym źródłem jonów cynku dla środowiska. Naukowcy dowiedli również, że w czasie kilku miesięcy w wodach symulujących warunki naturalne nanocząstki ZnO zmieniają swoją wielkość i kształt oraz że toksyczność ZnO NPs należy tłumaczyć rozpuszczaniem ZnO NPs i toksycznością powstających jonów Zn ${ }^{2+}$ [65].

Ze względu na wszechobecność substancji humusowych nanocząstki metali uwolnione do środowiska mogą łączyć się z MO i zyskać powłokę $\mathrm{KH} / \mathrm{KF}$. W wyniku tego procesu przemiany 
behaviour, transport and toxicity of nanosubstances in the aquatic environment. Understanding aggregation is of crucial importance as lower aggregation results in a lower sedimentation rate and a higher mobility of compounds. The stability of nanocompounds is another highly significant factor in determining their bioavailability and toxicity. It should be emphasised that studies have demonstrated that HA/FA had a variable effect on the toxicity of NOMPs to organisms. For example, HA may reduce the antibacterial activity of $\mathrm{Ag}$ and $\mathrm{CeO}_{2}$ nanoparticles [24], and $\mathrm{FA}$ may reduce the antibacterial activity of $\mathrm{CuO}$ [66] nanoparticles. In contrast, the presence of $\mathrm{HA}$ may increase the toxicity of $\mathrm{TiO}_{2}$ nanoparticles in the process of zebrafish growth [67]. For this reason, determining the behaviour of nanoparticles requires a thorough in situ characterisation under environmentally-relevant conditions.

\section{Summary and conclusions}

Metal and metal oxide nanoparticles are becoming increasingly popular in various areas of life, which makes them a rising group of compounds released to the environment, including to surface waters. Due to the significance of water bodies for the economy and pollutant migration, the presence of nanosubstances is a very important issue. Given the toxicity of NOMPs towards various forms of living organisms, it is essential to obtain knowledge about their functioning in aquatic ecosystems and their interactions with substances present in such solutions.

The analysis of various literature sources indicates that the size, structure and layout of nanoparticles and the size and properties of the surface are subject to constant change in the environment due to interactions with other components and equilibria shaped by diverse bio- and geochemical factors. The size distribution of particles may therefore be subject to change in response to the occurring reactions, such as sorption, aggregation, precipitation, dissolution and the processes determined by the presence of microbes. There are a large number of cases where grain sizes change from the nano to the micro and macro scales, which also causes changes in the sizes of the analysed compounds.

However, it should be emphasised that most conducted studies still involve model laboratory conditions with high nanoparticle concentration and a distilled water matrix, which does not accurately reflect the natural conditions present in surface waters [68]. Therefore, it is necessary to start developing exposure models, which would require collecting data on the features, possibilities of release and behaviour of NPMOs in surface waters. It is necessary to study the mechanisms and kinetics of processes occurring in the aquatic environment with regard to metal and metal oxide nanoparticles to estimate the actual or potential threats to the environment and people. transport i toksyczność nanosubstancji w środowisku wodnym mogą ulec zmianie. Zrozumienie agregacji ma kluczowe znaczenie, ponieważ mniejsza agregacja daje niższe tempo sedymentacji i większą mobilność związków. Stabilność nanozwiązków jest również istotna przy określaniu ich biodostępności i toksyczności. Należy podkreślić, że badania pokazały, że KH/KF miały różny wpływ na toksyczność NPMOs w stosunku do organizmów. Na przykład KH może zmniejszyć aktywność przeciwbakteryjną nanocząstek $\mathrm{Ag}$ i $\mathrm{CeO}_{2}$ [24], a KF może zmniejszyć aktywność przeciwbakteryjną nanocząstek CuO [66]. Przeciwnie, obecność $\mathrm{KH}$ może zwiększyć toksyczność nanocząstek $\mathrm{TiO}_{2} \mathrm{w}$ procesie rozwoju Danio pręgowanego [67]. Dlatego też określenie zachowania nanocząstek wymaga wnikliwej charakterystyki in situ w warunkach istotnych dla środowiska.

\section{Podsumowanie i wnioski}

Nanocząstki metali i tlenków metali znajdują coraz powszechniejsze stosowanie w różnych dziedzinach życia człowieka, co powoduje, że stanowią istotną grupę związków emitowanych do środowiska, w tym do wód powierzchniowych. Ze względu na rolę wód w gospodarce człowieka oraz w migracji zanieczyszczeń obecność nanosubstancji jest bardzo istotnym zagadnieniem. Problem toksyczności NPMOs w odniesieniu do różnych form organizmów żywych sprawia, że niezbędna staje się wiedza w zakresie ich funkcjonowania w ekosystemach wodnych oraz interakcji z obecnymi w tych roztworach substancjami.

Analiza poszczególnych doniesień literaturowych wskazuje, że wielkość nanocząstek, ich budowa, układ oraz wielkość i właściwości powierzchni podlegają ciągłym zmianom w środowisku w wyniku interakcji z innymi składnikami i równowag kształtowanych przez różnorodne czynniki bio-i geochemiczne. Rozkład wielkości cząstek może zatem ulec zmianie w odpowiedzi na zachodzące reakcje, takie jak sorpcja, agregacja, strącanie, rozpuszczanie oraz procesy uwarunkowane obecnością mikroorganizmów. W wielu sytuacjach mamy do czynienia ze zmianą wielkości ziaren ze skali nano do skali mikro i makro, co powoduje także zmianę właściwości analizowanych związków.

Należy jednak zaznaczyć, że większość prowadzonych badań dotyczy wciąż warunków laboratoryjnych, modelowych przy znacznym stężeniu nanocząstek, w których jako matryca stosowana jest woda destylowana, co nie odpowiada warunkom naturalnym, panującym w wodach powierzchniowych [68]. Niezbędne jest zatem podjęcie prac $w$ zakresie opracowania modeli ekspozycji. To z kolei wymaga gromadzenia danych odnoszących się do cech i możliwości uwalniania NPMOs w wodach powierzchniowych. W celu oszacowania rzeczywistego lub potencjalnego zagrożenia dla środowiska i ludzi konieczne jest poznanie mechanizmów oraz kinetyki procesów zachodzących w środowisku wodnym w odniesieniu do nanocząstek metali i tlenków metali. 


\section{List of abbreviations}

$\begin{array}{ll}\text { NPs } & \text { - nanoparticles } \\ \text { NPMOs } & \text { - nanoparticles of metal and metal oxides } \\ \text { NOM } & \text { - natural organic matter } \\ \text { OM } & \text { - organic matter } \\ \text { HA } & \text { - humic acids } \\ \text { FA } & \text { - fulvic acids } \\ \text { HnA } & \text { - humin acids } \\ \text { pH } & \text { - pH } \text { at the point of zero charge } \\ \text { PZC } & \text { - point of zero charge } \\ \text { HS } & \text { - humic substances } \\ \text { SPM } & \text { - Suspended Particulate Matter }\end{array}$

\section{Literature / Literatura}

[1] Tomczyk-Wydrych I., Rabajczyk A., Nanocząstki metali w wodach powierzchniowych - zagrożenie dla organizmów wodnych, Safety \& Fire Technology 2019, 54.

[2] Amde M., Liu J., Tan Z-Q., Bekana D., Transformation and bioavailability of metal oxide nanoparticles in aquatic and terrestrial environments. A review, "Environmental Pollution" 2017, 230, 250-267, https://doi.org/10.1016/j.envpol.2017.06.064.

[3] Bundschuh M., Filser J., Lüderwald S., McKee M. S., Metreveli G., Schaumann G.E., Schulz R., Wagner S., Nanoparticles in the environment: where do we come from, where do we go to?, "Environmental Sciences Europe" 2018, 30, 6, https://doi.org/10.1186/s12302-018-0132-6.

[4] Buzea C, Pachec I. I., Robbie K., Nanomaterials and nanoparticles: Sources and toxicity, "Biointerphases" 2007, 2, 4, 17-71, https://doi.org/10.1116/1.2815690.

[5] Christian P., Von der Kammer F., Baalousha M., Hofmann T., Nanoparticles: structure, properties, preparation and behavior in environmental media, "Ecotoxicology" 2008, 17, 326-343, https://doi.org/10.1007/s10646-008-0213-1.

[6] Gulliver J. S., Air-Water Mass Transfer Coefficients, w. Handbook of Chemical Mass Transport in the Environment, Thibodeaux L. J., Mackay D. (red.), Taylor and Francis Group, LLC, 2011.

[7] Thibodeaux L. J., Justin E., Birdwell J. E., Reible D. D., Diffusive Chemical Transport across Water and Sediment Boundary Layers, w: Handbook of Chemical Mass Transport in the Environment, Thibodeaux L. J., Mackay D. (red.), Taylor and Francis Group, LLC, 2011.

[8] Markus A. A., Parsons J. R., Roex E. W. M., de Voogt P., Laane R. W. P M., Modeling aggregation and sedimentation of nanoparticles in the aquatic environment, "Journal \& Books" 2015, 506-507, 323-329, https://doi.org/10.1016/j. scitotenv.2014.11.056.

[9] Rabajczyk A., Sykała E., The role of suspended matters as solid supporters of heavy metals in water environment, "Humic Substances in Ecosystems" 2009, 8, 134-141.

[10] Handy R. D., Owen R., Valsami-Jones E., The ecotoxicology of nanoparticles and nanomaterials: current status, knowledge gaps, challenges, and future needs, "Ecotoxicology" 2008, 17, 5, 315-325, https://doi.org/10.1007/s10646-008-0206-0.

\section{Wykaz skrótów}

$\begin{array}{ll}\text { NPs } & \text { - nanocząstki } \\ \text { NPMOs } & \text { - nanocząstki metali i tlenków metali } \\ \text { NOM } & \text { - naturalna materia organiczna } \\ \text { MO } & \text { - materia organiczna } \\ \text { KH } & \text { - kwasy humusowe } \\ \text { KF } & \text { - kwasy fulwowe } \\ \text { KHu } & - \text { kwasy huminowe } \\ \text { pH } & \text { - wartość pH zbliżonej do punktu } \\ & \quad \text { zerowego ładunku } \\ \text { PZC } & - \text { punktu zerowego ładunku } \\ \text { SH } & - \text { substancje humusowe } \\ \text { SPM } & - \text { zawiesina }\end{array}$

[11] Muller N. C., Nowack B., Exposure Modeling of Engineered Nanoparticles in the Environment, "Environmental Science \& Technology" 2008, 42, 4447-4453, https://doi.org/10.1016/j. impact.2017.06.005.

[12] Najafpour M. M., Isaloo M. A., Eaton-Rye J. J., Tomo T., Nishihara H., Satoh K., Carpentier R., Shen J., Allakhverdiev S. I., Water exchange in manganese-based water-oxidizing catalysts in photosynthetic systems: From the water oxidizing complex in photosystem II to nano-sized manganese oxides, "Biochimica et Biophysica Acta" 2014, 16, 2-14, https://doi.org/10.1016/j. bbabio.2014.03.008.

[13] Klaine S. J., Alvarez P. J. J., Batley G. E., .Fernandes T. F, Handy R. D., Lyon D. Y., Mahendra S., McLaughlin M. J., Lead J. R., Nanomaterials in the environment: Behavior, fate, bioavailability, and effects, "Environmental Toxicology \& Chemistry" 2008, 27, 9, 1825-1851.

[14] Navarro E., Baun A., Behra R., Hartmann N. B., Filser J., Miao A. J., Quigg A., Santschi P. H., Sigg L., Environmental behavior and ecotoxicity of engineered nanoparticles to algae, plants, and fungi, "Ecotoxicology" 2008, 17, 5, 372386, https://doi.org/10.1007/s10646-008-0214-0.

[15] Jahan S, Yusoff I. B., Alias Y. B., Bakar A. F. B. A., Reviews of the toxicity behawior of five potential engineered nanomaterials (ENMs) into the aquatic ecosystem, "Toxicology Reports" 2017, 4, 211-220, https://doi.org/10.1016/j. toxrep.2017.04.001.

[16] VanLoon G. W., Duffy S. J., Chemia środowiska, Wydawnictwo Naukowe PWN, Warszawa 2007.

[17] Kowal A. L., Świderska-Bróź M., Oczyszczanie wody, Wydawnictwo Naukowe PWN, Warszawa 2007.

[18] Darko B., Jiang J-Q., Kim H., Machala L., Zboril R., Sharma V. K., Advances Made in Understanding the Interaction of Ferrate(VI) with Natural Organic Matter in Water, “Water Reclamation and Sustainability" 2014, 183-197, https://doi.org/10.1016/B978-0-12-411645-0.00008-0.

[19] Ghosh S., Mashayekhi H., Pan B., Bhowmik P., Xing B., Colloidal Behavior of Aluminum Oxide Nanoparticles As Affected by $\mathrm{pH}$ and Natural Organic Matter, "Langmuir" 2008, 24, 12385-12391, https://doi.org/10.1021/la802015f. 
[20] Kim J. K., Alajmy J., Borges A. C., Joo J. Ch., Ahn H., Campos L. C., Degradation of Humic Acid by Photocatalytic Reaction Using Nano-sized ZnO/Laponite Composite (NZLC), "Water Air \& Soil Pollution" 2013, 224, 1749, https://doi.org/10.1007/s11270-013-1749-0.

[21] Linnik P. N., Ivanechko Ya. S., Linnik R. P., Zhezherya V. A., Humic Substances in Surface Waters of the Ukraine, "Russian Journal of General Chemistry" 2013, 83, 13, 27152730, https://doi.org/10.1134/S1070363213130185.

[22] Rabajczyk A., Namieśnik J., Speciation of iron in the aquatic environment, "Water Environment Research" 2014, 86, 8, 741-758, https://doi.org/10.2175/10614301 $4 \times 13975035525906$.

[23] Loosli F., Le Coustumer P., Stoll S., Effect of natural organic matter on the disagglomeration of manufactured $\mathrm{TiO}_{2}$ nanoparticles, “Environmental Science: Nano" 2014, 1, 154-160, https://doi.org/10.1039/c3en00061c.

[24] Fabrega J., Fawcett S. R., Renshaw J. C., Lead J. R., Silver nanoparticle impact on bacterial growth: effect of $\mathrm{pH}$, concentration, and organic matter, "Environmental Science Technology" 2009, 43, 19, 7285-90, https://doi.org/10.1021/es803259g.

[25] Zhang Y., Chen Y., Westerhoff P. Crittenden J., Impact of natural organic matter and divalent cations on the stability of aqueous nanoparticles, "Water Research" 2009, 43, 17, 4249-4257, https://doi.org/10.1016/j.watres.2009.06.005.

[26] Zhu X., Wang J., Zhang X., Chang Y., Chen Y., The impact of $\mathrm{ZnO}$ nanoparticle aggregates on the embryonic development of zebrafish (Danio rerio), "Nanotechnology" 2009, 20, 19, https://doi.org/10.1088/0957-4484/20/19/195103.

[27] Yu S., Liu J., Yin Y., Shen M., Interactions between engineered nanoparticles and dissolved organic matter: A review on mechanisms and environmental effects, "Journal of Environmental Sciences" 2018, 63, 198-217, https://doi. org/10.1016/j.jes.2017.06.021.

[28] Lin D., Cai P., Peacock C. L., Wu Y., Gao C., Peng W., Huang Q., Liang W., Towards a better understanding of the aggregation mechanisms of iron (hydr)oxide nanoparticles interacting with extracellular polymeric substances: $\mathrm{Role}$ of $\mathrm{pH}$ and electrolyte solution, "Science of the Total Environment" 2018, 15, 645, 372-379, https://doi.org/10.1016/j.scitotenv.2018.07.136.

[29] Lin D., Story S. D., Walker S. L., Huang Q., Liang W., Cai P., Role of $\mathrm{pH}$ and ionic strength in the aggregation of $\mathrm{TiO}^{2}$ nanoparticles in the presence of extracellular polymeric substances from Bacillus subtilis, "Environmental Pollution", 2017, 228, 35-42, https://doi.org/10.1016/j. envpol.2017.05.025

[30] Erhayem M., Sohn M., Effect of humic acid source on humic acid adsorption onto titanium dioxide nanoparticles, "Science of the Total Environment" 2014, 470-471, 92-98, https://doi.org/10.1016/j.scitotenv.2013.09.063.

[31] Chen G., Liu X., Su Ch., Distinct Effects of Humic Acid on Transport and Retention of $\mathrm{TiO}_{2}$ Rutile Nanoparticles in Saturated Sand Columns, "Environmental Science \& Technology" 2012, 46, 7142-7150, https://doi.org/10.1021/es204010g.

[32] Thio B. J. R., Zhou D., Keller A. A., Influence of natural organic matter on the aggregation and deposition of tita- nium dioxide nanoparticles, "Journal of Hazardous Materials" 2011, 189, 556-563, https://doi.org/10.1016/j. jhazmat.2011.02.072.

[33] Zhu M., Wang H, Keller A. A., Wang T., Li F., The effect of humic acid on the aggregation of titanium dioxide nanoparticles under different $\mathrm{pH}$ and ionic strengths, "Science of the Total Environment" 2014, 15, 487, 375-380, https://doi.org/10.1016/j.scitotenv.2014.04.036.

[34] Luo M., Huang Y., Zhu M., Tang Y., Ren T., Ren J., Wang H., Li F., Properties of different natural organic matter influence the adsorption and aggregation behawior of $\mathrm{TiO}_{2}$ nanoparticles, "Journal of Saudi Chemical Society" 2018, 22, 146154, https://doi.org/10.1016/j.jscs.2016.01.007.

[35] Yang K., Lin D. H., Xing B. S., Interactions of humic acid with nanosized inorganic oxides, "Langmuir" 2009, 25, 35713576, https://doi.org/10.1021/la803701b.

[36] Cumberland S. A., Lead J. R., Particle size distributions of silver nanoparticles at environmentally relevant conditions, "Chromatography A" 2009, 1216, 90-99.

[37] Baalousha M., Aggregation and disaggregation of iron oxide nanoparticles: influence of particle concentration, $\mathrm{pH}$ and natural organic matter, "Science of the Total Environment" 2009, 407, 2093-2101, https://doi.org/10.1016/j. scitotenv.2008.11.022.

[38] Labille J., Brant J., Stability of nanoparticles in water, "Nanomedicine" 2010, 5, 6, 985-998, https://doi.org/10.2217/ nnm.10.62.

[39] Gottschalk F., Nowack B., The release of engineered nanomaterials to the environment, "Journal of Environmental Monitoring" 2011, 13, 5, 1145-1155, https://doi. org/10.1039/c0em00547a.

[40] Domingos R. F., Tufenkji N., Wilkinson K. J., Aggregation of Titanium Dioxide Nanoparticles: Role of a Fulvic Acid, “Environmental Science \& Technology" 2009, 43, 5, 12821286, https://doi.org/10.1021/es8023594.

[41] Keller A. A., Wang H., Zhou D., Lenihan H. S., Cherr G., Cardinale B. J., Miller R., Ji Z., Stability and aggregation of metal oxide nanoparticles in natural aqueous matrices, "Environmental Science \& Technology" 44, 6, 2010, 19621967, https://doi.org/10.1021/es902987d.

[42] Li K., Chen Y., Effect of natural organic matter on the aggregation kinetics of $\mathrm{CeO}_{2}$ nanoparticles in $\mathrm{KCl}$ and $\mathrm{CaCl}_{2}$ solutions: Measurements and modeling, "Journal of Hazardous Materials" 2012, 209-210, 264-270, https://doi.org/ 10.1016/j.jhazmat.2012.01.013.

[43] Liu X., Wazne M., Chou T., Xiao R., Xu S., Influence of $\mathrm{Ca}^{2+}$ and Suwannee River Humic Acid on aggregation of silicon nanoparticles in aqueous media, "Water Research" 2011, 45, 1, 105-112, https://doi.org/10.1016/j. watres.2010.08.022.

[44] Jiang Ch., Aiken G. R., Hsu-Kim H., Effects of Natural Organic Matter Properties on the Dissolution Kinetics of Zinc Oxide Nanoparticles, "Environmental Science \& Technology “ 2015, 49, 19, 11476-11484, https://doi.org/10.1021/acs.est.5b02406.

[45] Jiang X., Tong M., Kim H., Influence of natural organic matter on the transport and deposition of zinc oxide na- 
noparticles in saturated porous media, "Journal of Colloid and Interface Science" 2012, 386, 34-43, https://doi.org/10.1016/j.jcis.2012.07.002.

[46] Chen G., Liu X., Su Ch., Distinct Effects of Humic Acid on Transport and Retention of $\mathrm{TiO}_{2}$ Rutile Nanoparticles in Saturated Sand Columns, "Environmental Science \& Technology" 2012, 46, 7142-7150, https://doi.org/10.1021/es204010g.

[47] Manoharan V., Ravindran A., Anjali C. H., Mechanistic insights into interaction of humic acid with silver nanoparticles, "Cell Biochemistry Biophysics" 2014, 68, 127-131, https:// doi.org/10.1007/s12013-013-9699-0.

[48] Akhil K., Chandran P., Khan S. S., Influence of humic acid on the stability and bacterial toxicity of zinc oxide nanoparticles in water, "Journal of Photochemistry \& Photobiology" 2015, B: Biology 153, 289-295, https://doi.org/10.1016/j. jphotobiol.2015.10.007.

[49] Jahan S., Yusoff I. B., Alias Y. B., Bakar A. F. B. A., Reviews of the toxicity behawior of five potential engineered nanomaterials (ENMs) into the aquatic ecosystem, "Toxicology Reports" 2017, 4, 211-220, https://doi.org/10.1016/j. toxrep.2017.04.001.

[50] Ashraf M. A., Peng W., Zare Y., Rhee K. Y., Effects of Size and Aggregation/Agglomeration of Nanoparticles on the Interfacial/Interphase Properties and Tensile Strength of Polymer Nanocomposites, "Nanoscale Research Letters" 2018, 13, 214, https://doi.org/10.1186/s11671-018-2624-0.

[51] Illés E., Tombácz E., The effect of humic acid adsorption on $\mathrm{pH}$-dependent surface charging and aggregation of magnetite nanoparticles, "Journal of Colloid and Interface Science" 2006, 295, 115-123, https://doi.org/10.1016/j. jcis.2005.08.003.

[52] Baruah B., Dutta J., pH-dependent growth of zinc oxide nanorods, "Journal of Crystal Growth" 2019, 311, 8, 25492554, https://doi.org/10.1016/j.jcrysgro.2009.01.135.

[53] Alias S., Ismail A. B., Mohamad A. A., Effect of $\mathrm{pH}$ on ZnO nanoparticle properties synthesized by sol-gel centrifugation, "Journal of Alloys Compounds" 2010, 499, 2, 231-237, https://doi.org/10.1016/j.jallcom.2010.03.174.

[54] Bian S. W., Mudunkotuwa I. A., Rupasinghe T., Grassian V. H., Aggregation anddissolution of $4 \mathrm{~nm} \mathrm{ZnO}$ nanoparticles in aqueous environments: influence of $\mathrm{pH}$, ionic strength, size, and adsorption of humic acid, "Langmuir" 2011, 27, 60596068, https://doi.org/10.1021/la200570n.

[55] Zhang R., Zhang H., Tu Ch., Hu X., Li L., Luo Y., Christie P., Facilitated transport of titanium dioxide nanoparticles by humic substances in saturated porous media under acidic conditions, "Journal of Nanoparticle Research" 2015, 17, 165, https://doi.org/10.1007/s11051-015-2972-y.

[56] Liu W. S., Peng Y. H., Shiung C. E., Shih Y., The effect of cations on the aggregation of commercial $\mathrm{ZnO}$ nanoparticle suspension, "Journal of Nanoparticle Research" 2012, 14, 12, 1259, https://doi.org/10.1007/s11051-012-1259-9.

[57] Liu G., Wang D., Wang J., Mendoza C., Effect of ZnO particles on activated sludge: Role of particle dissolution, "Science of the Total Environment" 2011, 409, 14, 2852-2857, https://doi.org/10.1016/j.scitotenv.2011.03.022.
[58] Xia T., Kovochich M., Liong M., Madler L., Gilbert B., Shi H., Yeh J. I., Zink J. I., Nel A. E., Comparison of the mechanism of toxicity of zinc oxide and cerium oxide nanoparticles based on dissolution and oxidative stress properties, "ACS Nano" 2008, 2, 10, 2121-2134, https://doi.org/10.1021/nn800511k.

[59] Tang W. W., Zeng G. M., Gong J. L., Liang J., Xu P., Zhang Ch., Huang B.-B., Impact of humic/fluvic acid on the removal of heavy metal from aqueous solutions using nanomaterials: A review, "Science of the Total Environment" 2014, 468, 469, 1014-1027, https://doi.org/10.1016/j. scitotenv.2013.09.044.

[60] Zhu M., Wang H., Keller A. A., Wang T., Li F., The effect of humic acid on the aggregation of titanium dioxide nanoparticles under different $\mathrm{pH}$ and ionic strengths, "Science of the Total Environment" 2014, 15, 487, 375-380, https://doi. org/10.1016/j.scitotenv.2014.04.036.

[61] Han Y., Kim D., Hwang G., Lee B., Eom I., Kim P. J., Tong M., Kim H., Aggregation and dissolution of $\mathrm{ZnO}$ nanoparticles synthesized bydifferent methods: Influence of ionic strength and humic acid, "Colloids and Surfaces A: Physicochemical and Engineering Aspects" 2014, 451, 7-15, https://doi.org/10.1016/j.colsurfa.2014.03.030.

[62] Luo M., Huang Y., Zhu M., Tang Y., Ren T., Ren J., Wang H., Li F., Properties of different natural organic matter influence the adsorption and aggregation behawior of $\mathrm{TiO}_{2}$ nanoparticles, „Journal of Saudi Chemical Society" 2018, 22, 146154, https://doi.org/10.1016/j.jscs.2016.01.007.

[63] Rabajczyk A., El Yamani N., Dusinska M., The effect of time on the stability of iron oxide nanoparticles in environmental acids, „Water Environment Research” 2017, 89, 5, 416-423, https://doi.org/10.2175/106143016X14609975747685.

[64] Quik J. T. K., Lynch I., Van Hoecke K., Miermans C. J. H., De Schamphelaere K. A. C., Janssen C. R., Dawson K. A., Cohen Stuart M. A., Van De Meent D., 2010: Effect of Natural Organic Matter on Cerium Dioxide Nanoparticles Settling in Model Fresh Water, “Chemosphere” 2010, 81, 6, 711-715, https://doi.org/10.1016/j.chemosphere.2010.07.062.

[65] Lopes S., Ribeiro F., Wojnarowicz J., Łojkowski W., Jurkschat K., Crossley A., Soares A. M. V. M., Loureiro S., Zinc oxide nanoparticles toxicity to Daphnia magna: size-dependent effects and dissolution, „Environmental Toxicology and Chemistry" 2014, 33, 190-198, https://doi. org/10.1002/etc. 2413.

[66] Zhao J., Wang Z. Y., Dai Y. H., Xing B. S., Mitigation of CuO nanoparticle-induced bacterial membrane damage by dissolved organic matter, "Water Research" 2013, 47, 12, 1-10, https://doi.org/10.1016/j.watres.2012.11.058.

[67] Yang S. P., Bar-Ilan O., Peterson R.E., Heideman W., Hamers R. J., Pedersen J.A., Influence of humic acid on Titanium dioxide nanoparticle toxicity to developing zebrafish, „Environmental Science \&Technology” 2013, 47, 9 , 4718-4725, https://doi.org/10.1021/es3047334.

[68] Talia E. Abbott Chalew and Kellogg J. Schwab, Are nanoparticles a threat to our drinking water? Johns Hopkins University Water Institute, https://ehe.jhu.edu/water, [dostęp: 08.09.2012]. 
ILONA TOMCZYK-WYDRYCH, M.SC. - she graduated from the Jan Kochanowski University in Kielce in the field of Environmental Protection with a specialization in environmental monitoring and environmental management. Employee of State Water Holding Polish Waters. Scientific interests focus on migration of metal and metal oxides nanoparticles in the aquatic environment and their interaction with compounds present in surface waters.

ANNA RABAJCZYK, D.SC. - Associate Professor at the Scientific and Research Centre for Fire Protection - National Research Institute. She graduated from WSP in Kielce. Doctorate in chemistry at the University of Opole. Habilitation in environmental engineering at the Wrocław University of Technology. Environmental auditor. She has extensive scientific and didactic experience, and deals with issues to environmental engineering, nanotechnology, biotechnology as well as chemical transformation and environmental threats. She is an expert in national and international institutions (including NCBR, EC, The European Education and Training Expert Panel). She completed numerous both domestic and foreign internships and scholarships, she was a member in many scientific and organizational committees of both domestic and foreign conferences.
MGR ILONA TOMCZYK-WYDRYCH - Absolwentka Uniwersytetu Jana Kochanowskiego w Kielcach, kierunek ochrona środowiska o specjalności monitoring środowiska oraz zarządzanie środowiskowe. Pracownik Państwowego Gospodarstwa Wodnego Wody Polskie. Zainteresowania naukowe koncentrują się na migracji nanocząstek metali i tlenków metali w środowisku wodnym oraz ich interakcji z innymi związkami obecnymi w wodach powierzchniowych.

DR HAB. ANNA RABAJCZYK - profesor Centrum Naukowo-Badawczego Ochrony Przeciwpożarowej im. Józefa Tuliszkowskiego - Państwowego Instytutu Badawczego. Absolwent WSP w Kielcach, kierunek chemia. Doktorat $z$ chemii na Uniwersytecie Opolskim. Habilitacja z inżynierii środowiska na Politechnice Wrocławskiej. Audytor środowiskowy. Posiada bogate doświadczenie naukowe i dydaktyczne. Zajmuje się zagadnieniami inżynierii środowiska, nanotechnologii, biotechnologii oraz transformacji chemicznej i zagrożeń środowiskowych. Pełni rolę eksperta w krajowych i międzynarodowych instytucjach (m.in. NCBR, EC, The European Education and Training Expert Panel). Odbyła liczne staże i stypendia krajowe i zagraniczne, była członkiem w wielu komitetach naukowych i organizacyjnych konferencji zarówno krajowych, jak i zagranicznych. 